\title{
The Physicality and Spirituality of the Hindu Temples of Kerala
}

\author{
Binumol Tom
}

\begin{abstract}
Every culture can stir a type of architecture that can range from landmarks to everyday homes. History has proved that the various architectural styles have developed in response to climate, lifestyle, geology and geography of a place, religious philosophy of the people and availability of building materials. Religion and lifestyle seem to be the most common influences overall. Culture, in fact, underlines the important role that economics, politics, religion, heritage and the natural environment play in shaping the built environment. Kerala (the southern-most state of India), the land of temples appears unique in this context as the temples here were the pivot of religious, social, economic and cultural life of every Keralite. The typical Hindu temples of Kerala stand out from among the Indian temple typology in its form, structural clarity, stylistic tradition, symbolism and above all, in its construction and craftsmanship in wood. They show a distinctive style which is a local adaptation of the Dravida or the South Indian tradition of temple construction, considerably influenced by the various geographical, religious, cultural and political factors. Most of the temples of Kerala are traditionally neighborhood institutions of worship, rich in both tangible and intangible cultural values. The spatiality of Kerala temples follows the general Indian philosophical concepts of the centre, axis and the human relatedness to cosmic reality, while its implementation in the built form follows the Vedic religious practices. This paper attempts to explore the evolution of the generic built form of temples of Kerala and the philosophical and spatial concepts of their architecture.
\end{abstract}

\section{ARCHITECTURE AND CULTURE}

Architectural and anthropological thinkers, such as Lewis Morgan and Amos Rapoport, introduced the socio-cultural perspectives of our rich architectural heritage. Rapoport gives emphasis on culture by stating that a house is a cultural phenomenon; its form and organization are greatly influenced by cultural milieu to which it belongs.

Architecture is a cultural artifact that cannot be understood outside its cultural context and is dependent on the state of cultural evolution of the social group to which it belongs. The unique aspect of architecture is that in its physical incarnation of buildings, it may last for hundreds and hundreds of years. The most important architecture, as we look back over history, are buildings or environments that have done so much more in a variety of ways -be that innovation in building and construction, or buildings that have pushed the discipline to get us to think about our environment in different ways, or just incredibly beautiful buildings that have lifted the human spirit in addition to housing our activities and our lives.
Creative Space

Vol. 1, No. 2

January 2014

pp. 179-193

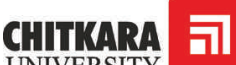
UNIVERSITY

(C)2014 by Chitkara University. All Rights

Reserved. 
Tom, B.

Regardless of the most severe physical constraints and technological limitations, men have been building in ways so strikingly diverse, that they can be attributed to choices which deliberately come from the culture. Any temple town in India gives testimony to the fact that an active cultural universal, such as religion, can give shape to a whole urban conglomeration with the abode of God as the focal point. And, so is the case with the towns of Kerala.

\section{THE PLACE, THE PEOPLE, THE CULTURE}

The land of Kerala is located in the southwestern coast of the Indian subcontinent and is endowed with a distinct topographical, cultural and linguistic identity. Kerala is a land of temples, and temples here are a pivot of religious, social, economic and cultural life. The geographical position of Kerala has had a major influence upon its architecture. The long stretch of coastal line along the west with its string of ports, and the protection provided by the natural barrier of the western ghats, have played a major role in shaping the history of Kerala.

Dravidians, the original inhabitants of northern India, are believed to have been driven south by the Aryan settlers from central Europe. They would have become the first settlers in Kerala, which was already inhabited by various tribes. The initial Aryan migrants were followers of Buddhism and Jainism and, thus, various Buddhist and Jain temples were believed to have been built during this period. Later, during the Vedic period (500BCE - 200 $\mathrm{CE}$ ), Brahminism of Aryans was introduced here, which brought in adoption of Vedic principles. During the time of Adi Shankaracharya (788-820 CE), a massive revival of Vedic thought was found in Kerala, resulting in the making of Hinduism a dominant religion over Jainism and Buddhism. But, with the advent of Brahmanical Hinduism, several Buddhist and Jain temples were converted to Hindu temples. The temples at Matilakam, Koodalmanikkam, Kallil, and Edakkal were believed to have been Jain in origin, while the Vadakkumnathan Temple at Thrissur and Siva Temple at Madavoorpara at Trivandrum were possibly Buddhist temples at an earlier date.

To every Keralite Hinduism was more a way of life than a religion. In olden times every action that he performed, and every building that he constructed, were governed by his strong religious beliefs. In the erection of a temple or a house, the selection of the site, the measurements followed, the date of commencement of the work, materials employed, the orientation of the structure, its layout and many other aspects; all had religious connotations which, if overlooked, were believed to displease the Gods and bring ill luck to people.

The structural activity, involving considerable expenditure, was a result of economic prosperity arising out of profitable external trade. This unique 


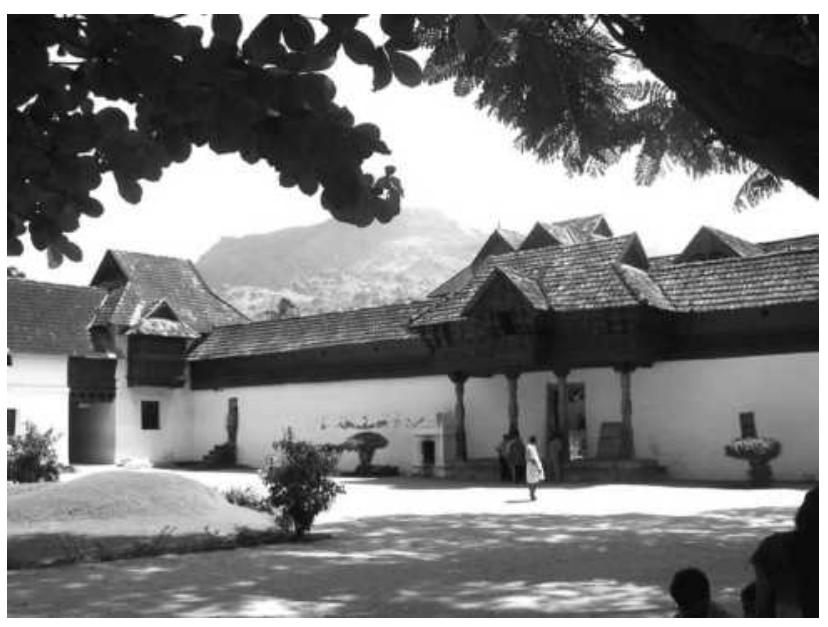

advantage of Kerala contributed greatly to the growth of temple architecture. The phenomenon of political fragmentation introduced a unifying trend in Kerala's temple architecture, which was to be guided largely by the principles of Vastusastra and efforts of Sthapathis (Architects, Master Builders). The cultural richness of Kerala stems from the interrelationship between religion, language, dance, music, visual arts and architecture. The syncretism of cultures and religions that occurred in Kerala over the centuries, that was brought by the waves of migration and trade relations, had profound influence in the development of construction practices in Kerala. Techniques that came to Kerala from foreign influences were adapted to suit the local climate, social structure and cultural practices.

\section{ARCHITECTURAL VOCABULARY OF THE PLACE}

The traditional architecture of Kerala comprises of temples and palace complexes along with tharavads (traditional houses) reflecting the unique wooden construction system of the region and is characterized by a high level of craftsmanship and building skill. Climate played a major role in deciding the architectural character of the place. Combined with the warm, humid climate of Kerala, the region's heavy rainfall dictated, to a great extent, the form and layout of traditional buildings. Some of these adaptations were buildings separated from other dwelling/ units, rooms opening into a central courtyard, steeply pitched roof with open gables at both ends, verandahs on almost all sides for residential buildings and deep overhangs (Fig. 1).
Figure 1: The dominating sloping roof and intricately carved wooden gables and marvel in wood -Padmanabhapuram Kerala (Image Source: Binumol Tom)
The Physicality And Spirituality Of The Hindu Temples

Of Kerala 
Tom, B.

The availability of timber and laterite from the dense jungles of Kerala produced a unique vocabulary of architecture. The ridge roof, pitched at angles between 30 to 40 degrees and placed over low walls, forms the main visual and functional element that renders Kerala Architecture a distinct identity. The dominating roof forms were embellished with intricately carved gables protruding from the roof with heaping overhangs sometimes supported by wooden brackets. In the earlier times the roof were covered with thatch which was replaced by tiles, and later, by metal cladding, especially for the religious structures.

\section{THE TEMPLE ARCHITECTURE OF KERALA}

The idea of having a place for public worship led to the rise of temples built generally by a collective endeavor. The variety of temples, numbering more than two thousand odd, dotting the Kerala state has no match with any other region of India. The temples are largely the local adaptation of Dravida or South Indian tradition, which was influenced considerably by various geographical and climatic factors like high precipitation, availability of laterite formation and dense jungles. Dated as early as the Twelfth Century, the Kerala temples are traditionally neighborhood institutions of worship with added functions of both knowledge and cultural centers. They stand head and shoulders above other Indian temples in "form, structural clarity, stylistic tradition, symbolism and above all in material and craftsmanship in wood".

Largely dictated by the geography of the region that abounds in forests and heavy monsoons, the Keralite temples are distinctinguished by steep and pointed roofs covered with copper sheets (Fig. 2). The central sanctum, the Sreekovil, is surrounded by a cloistered prakara, pierced at one or more cardinal points with a gopuradwara. The cloistered prakaram has a namaskara mandapam located directly in front of the sanctum. This prakaram also houses subsidiary shrines, temple tanks, vedopadesha shala (hall for teaching Vedas), oottupura (dining hall), and a kitchen located in its south eastern corner. The kuttambalam or the theater hall is located as a part of the inner prakara. The mukha mandapam is integrated with the gopuram entrance (Fig. 3)

\section{THE EVOLUTION OF THE GENERIC BUILT FORM - AMBALAM}

The temple architecture of Kerala can be divided into three phases. The first phase is that of rock cut temples dated prior to Eighth Century, which is contemporary to Buddhist Cave Temples. The generic pattern of the cave temple consists of a rock hewn shrine and an anteroom. Such cave temples were generally associated with Shiva worship (Figs. 4, 5, 6) 


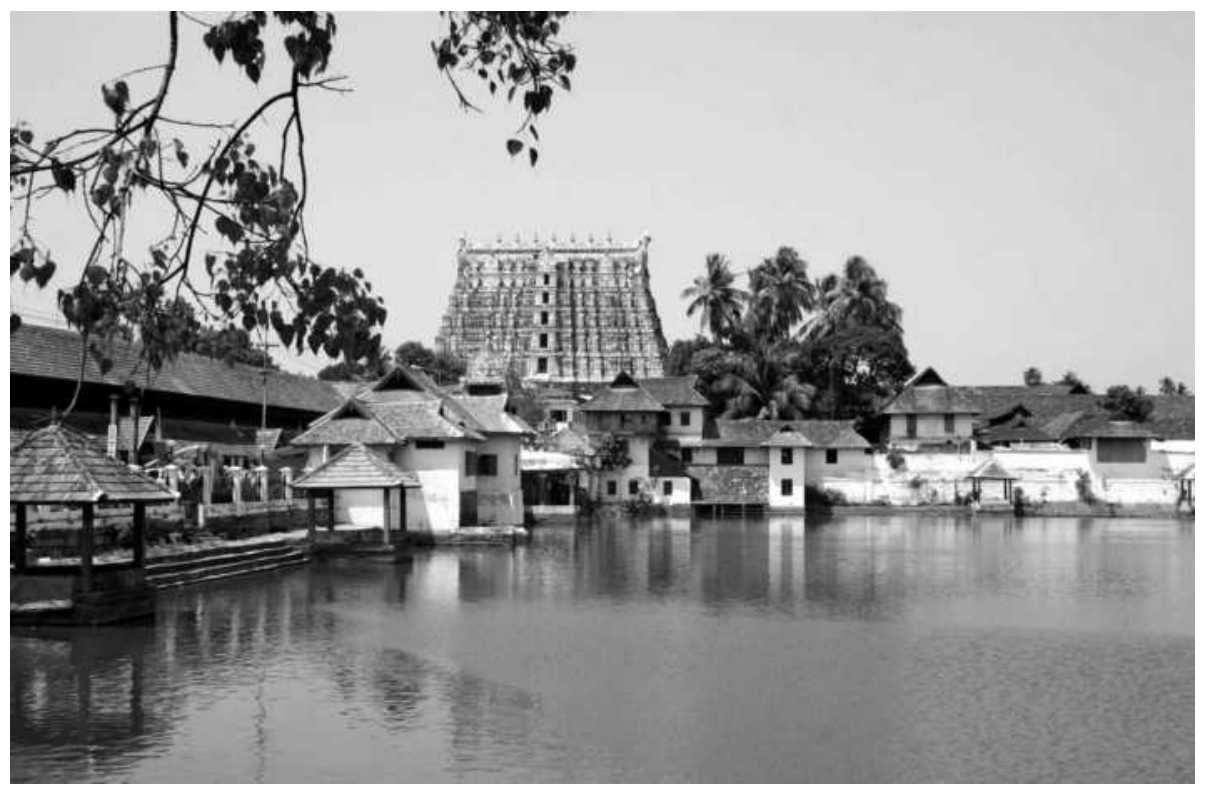

The Physicality And Spirituality Of The Hindu Temples Of Kerala

Figure 2: View of Sree Padmanabhaswami Temple, Thiruvananthapuram (Image Source: Binumol Tom)

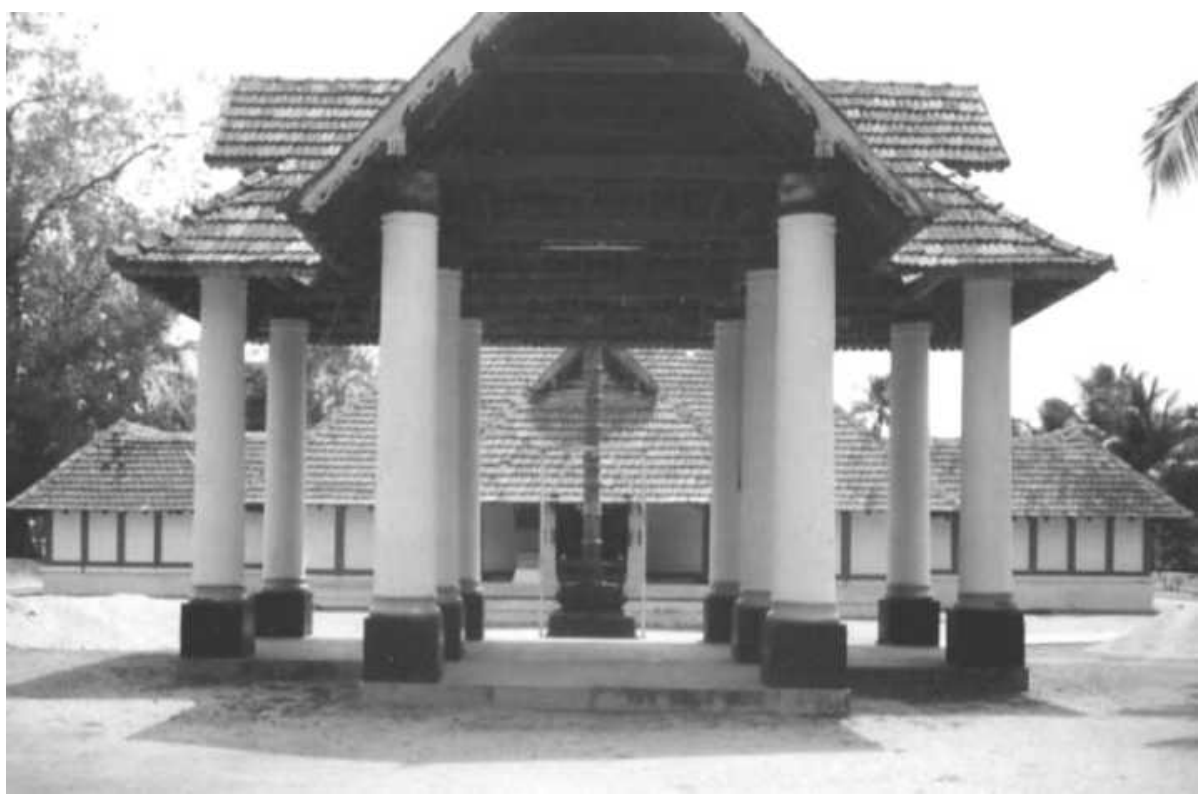

Figure 3: View of the temple enclosure seen through the anakottil (Image Sorce: Source: Binumol Tom) 
Tom, B.
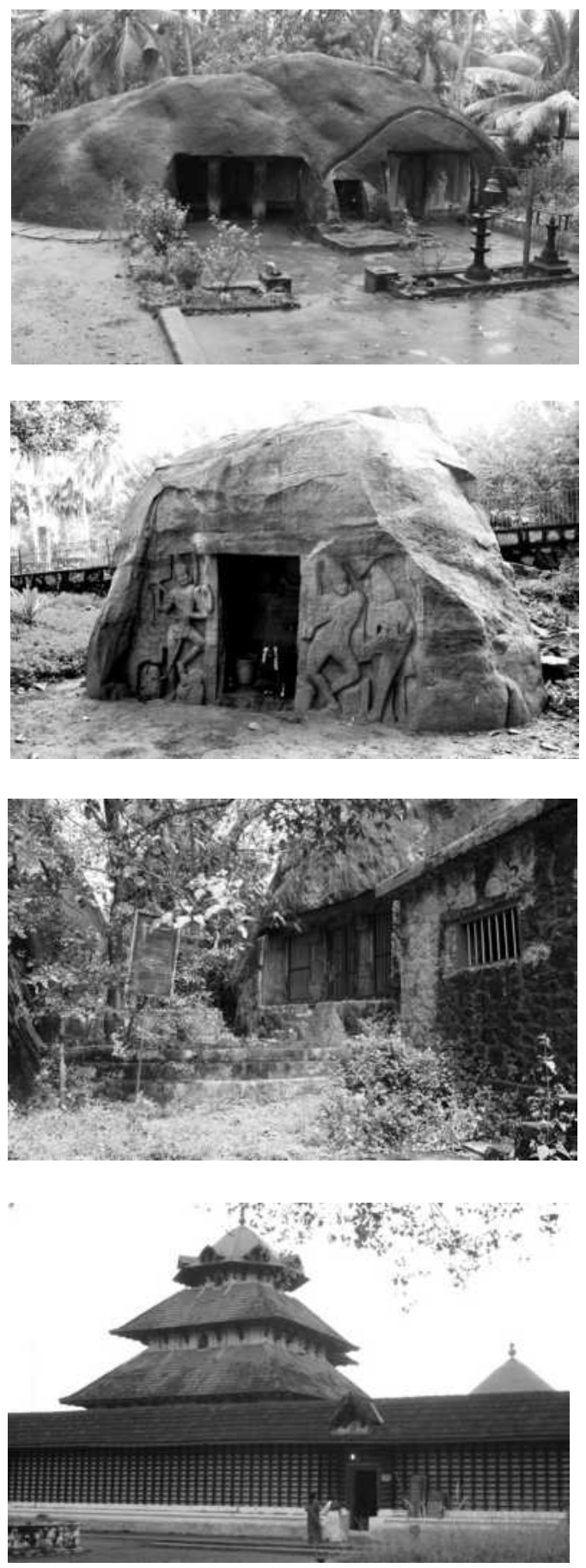

Figure 4: Kottukkal rock cut cave at Kollam (Image Source: Upload. wikimedia.org. Accessed on 12.11.2013)

Figure 5: Rock cut temple at Vizhijam (Image Source: Upload. wikimedia.org. Accessed on 12.11.2013)

Figure 6: Rock cut temple at Thrikkakkudi, Kaviyoor (Image Source: Vineeth G.)

Figure 7: The three storeyed (thrithala) shrine at Peruvanam Shiva Temple (Image Source: Binumol Tom) 


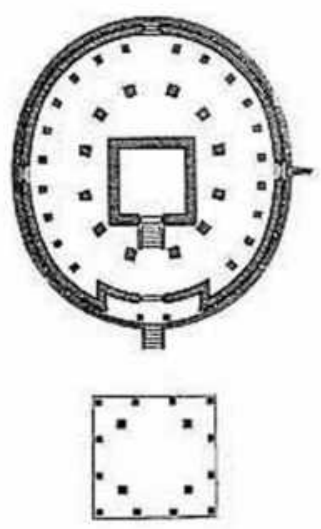

Round (Oval) Type (Shiva Temple, Vaikom)

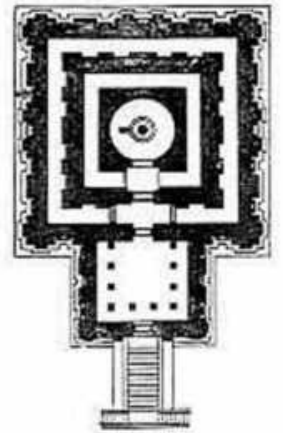

Square Type (Shiva Temple, Peruvanam)

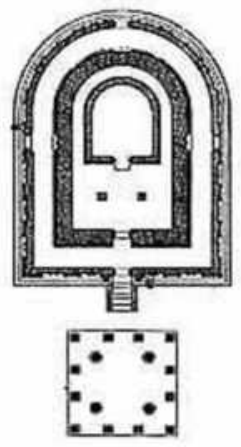

Apsidal Type

(Subrahmanya Temple, Payanur)
The Physicality And Spirituality Of The Hindu Temples

Of Kerala

Figure 8: The three types of the sreekovil of Kerala Temples (Image Source: Sarkar, 1978)

The second phase, spanning Eighth to Tenth Centuries, had an independent unitary shrine (sanctum sanctorum or garbhagriha or sreekovil) and, very rarely, an attached porch or arthamandapa. A detached namaskara mandapa is built in front of the sreekovil with an inner circumambulatory path (inner pradhakshinapada). A quadrangular building, nomenclatured as Nalambalam, encloses the sreekovil, the namaskara mandapa and the inner circumambulatory path. At the entrance to the nalambalam is located the altar stone (balikkal).

The unitary shrine of the earliest type was called nirandhara (a cell with the single doorway). Later, a cell with twin walls having a passage in between was developed from this concept which was known as sandhara shrine. This phase is also characterized by the concept of storeyed temples -- Dwithala (2 storeys) or Trithala (3 storeys). The tower of the shrine rises to the second or third storey with separate upper roofs forming dwithala or trithala temple (Fig. 7)

The basic plan composition of the Kerala temple began emerging in this phase. The sreekovil is built in different plan shapes square (nagara), rectangular, circular (vasara) polygonal (dravida) or apsidal (Fig. 8). The circular and apsidal plan types are rare in other parts of India but they constitute an important group of temples in Kerala under the influence of Buddhism. As Kerala had been following Vedic mooring, the square garbhagriha plan is evenly distributed. 
Tom, B.

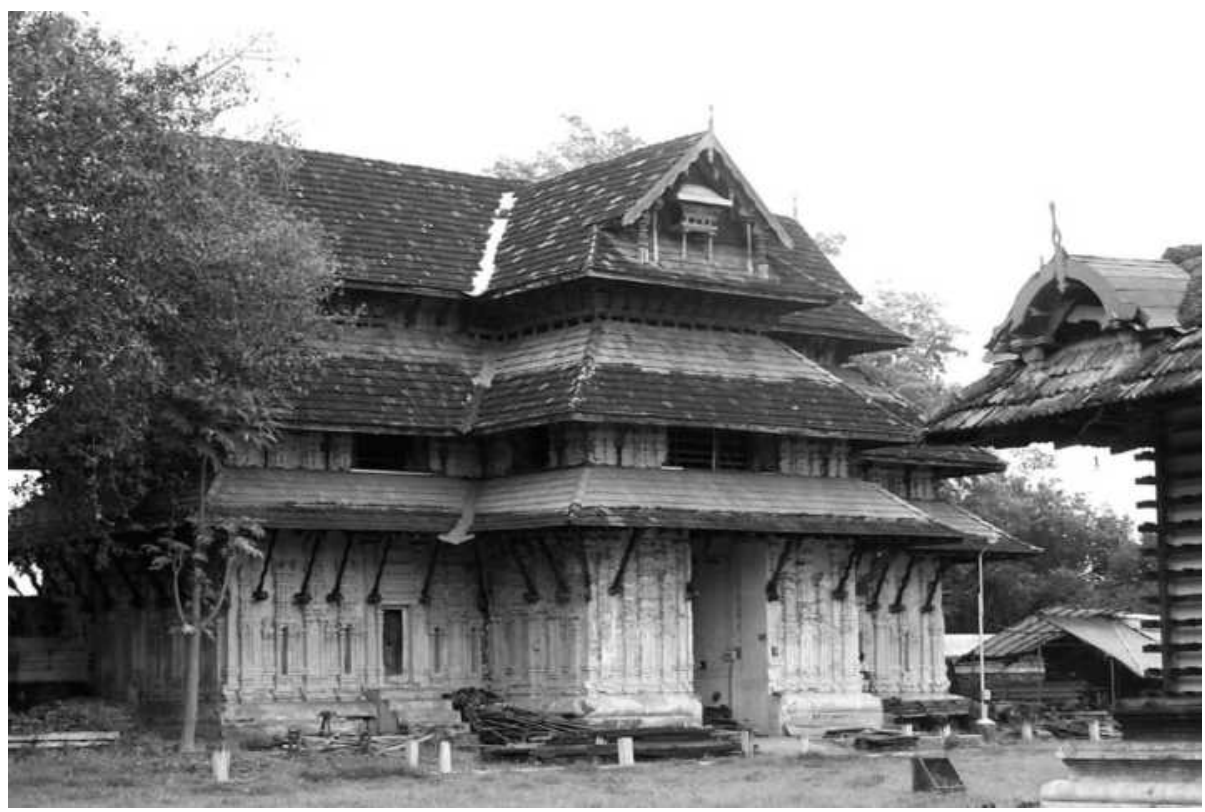

Figure 9: Western Gopuram (gateway) to Vadakkunnathan Temple in Thrissur. (Image Source: Binumol Tom)

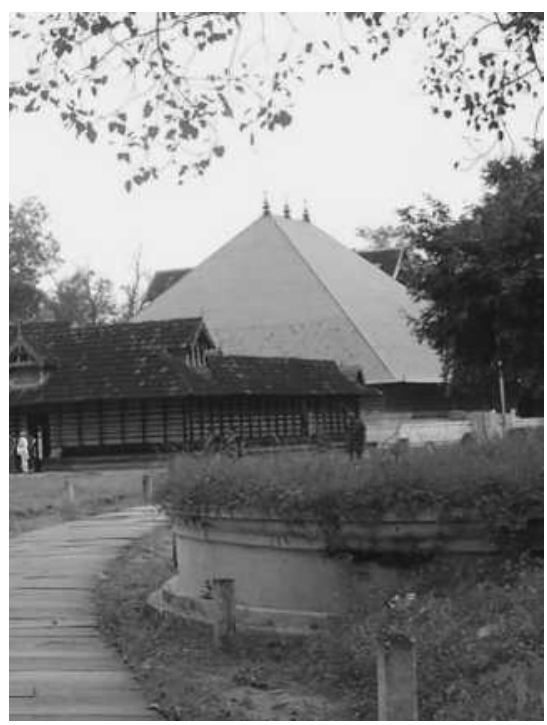

Figure 10: Koothambalam of Vadakkunnathan Temple in Thrissur (Image Source: Binumol Tom)

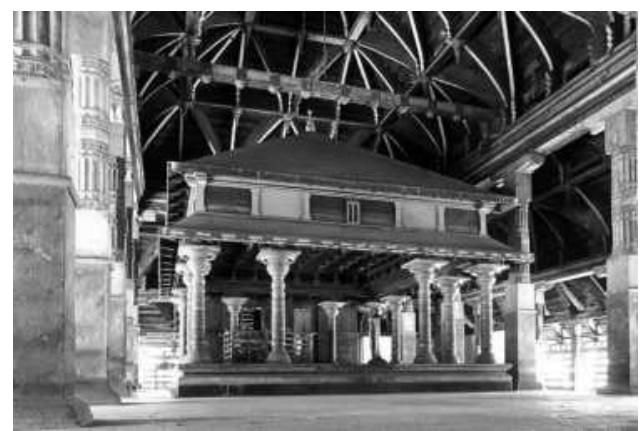

Figure 11: Wooden structure in the interior of the Koothambalam of Vadakkunnathan Temple in Thrissur (Image Source: www.kamit.jp/05_ wooden/7_palace/pal_eng.htm. Accessed on 22.01.14) 
For the unitary temple (Alpavimanas) the overall height is taken as $13 / 7$ to $21 / 8$ of the width of the shrine. The total height is basically divided into two halves. The lower half consists of the Basement (Adhisthana), the pillar or the wall (Sthamba or Bhithi) and the entablature (Prasthara) in the ratio 1:2:1. The upper half is divided into the neck (griva), the roof tower (Shikkaras) and the finial (Stupi) in the same ratio 1:2:1.

The Adistahana is generally in granite but the super structure is built in laterite. The structural roof of the shrine is constructed as the corbelled dome of masonry. However, in order to protect it from the vagaries of weather, it was superimposed by a functional roof made of timber frame covered by planks and tiles. This sloping roof, with its projecting eaves, gave the characteristic form. The finial, made of copper, provided the crowning spire, denoting the focus of the shrine under which the idol was installed.

In the last phase of evolution, the stylistic development of the Kerala Hindu Temple reached its climax. The temple layout now began exhibiting greater complexity with highly elaborate detailing. For example, the vilakkumadom palisade structure fixed with rows of lamps was now added beyond the nalambalam as an outer ring. The balikkal stone began to be housed in a pillared structure called balikkal mandapam. Further, a deepastambham (lamppost) and dwajasthambam (flagmast) were added in front of the balikkal mandapam. The temple was now fully enclosed in a massive wall called prakara pierced with gate houses or gopuras. The gopuras, which are generally two storeyed, serve the purpose of a platform for temples dances at the ground level and as kottupura, or space to accommodate drum beaters, at the upper floors (Fig. 9). Within the prakara but beyond the vilakkumadam stood the secondary shrines of parivaradevathas, which were unitary cells in their assigned positions according to vastusastric principles.

The last phase culminated in the concept of composite shrines, consisting two or three shrines of equal importance, cloistered inside a common nalambalam. The prakara may also contain temple tanks, vedopadesha shala (hall for teaching Vedas), oottupura (dining hall), and the koothambalam (theatre hall). The koothambalam is a unique edifice of Kerala temple architecture, distinct from the natyamandir of the north Indian temples, and is the traditional theatre attached to a temple for performing koothu and koodiyattam, and a space for other cultural activities related to the temple.

The design is based on the natyasastra of Bharathamuni. It is a large pillared hall with a high roof. Koothambalam are magnificent, highly ornate timber structures and are embodiment of acoustical genius of the builders. The very presence of koothambalams in temples stands as testimony that the temples were centre of cultural activities since early times. The koothambalam
The Physicality And Spirituality Of The Hindu Temples Of Kerala 
Tom, B.

at Vadakkunnatha Temple in Thrissur is one of the biggest architectural marvels, with enchantingly carved wooden pillars. The long wooden roof rafters and the gables are meticulously fixed, without use of iron nails (Fig. 10, 11).

\section{The 'Panchprakara' Layout}

During this final phase, the temple layout becomes more complex, creating the concept of panchprakara scheme consisting of Akathae balivattom (anthara mandapam), Chuttambalam (Anthahara), Vilakkumadom (Madhyahara), Shevelipura (Bahyahara) and Puramathil (Marvada), one of the best examples being the Vadakkumnatha temple at Thrissur ${ }^{1}$. In addition, this temple complex is a clear testimony of the synthesis and co-existence of various Brahmanical cults, as evinced from its cult images and ritual practices. This complex is clear evidence to the ever-expanding structural vistas in accordance to the evolving functional needs. In the Vadakkumnatha complex the three independent sreekovils (sanctum sanctorum) in north-south axis, are dedicated respectively to Lord Siva, Lord Sankaranarayana and Lord Rama. These are enclosed by a common enclosure (nalambalam). The circular sreekovil of Lord Siva, northern most of the row has its garbhagriha divided by a transverse diagonal wall. The western half, dedicated to Siva, has its own door opening and flight of steps in front with a detached namaskara mandapam. The eastern half is dedicated to Parvati, with the door opening on the east. The northern and southern cardinal points have ghanadwaras. On the stone adisthana, the outer sanctum wall and the prastara show the characteristic reliefs of pilasters, and miniature shrines of the kuta, sala and panjara models. The sloping conical roof of metal sheet covers these by its over-hanging eaves supported by brackets sprung from the walls at intervals. The inner wall, rising further above the outer wall, carries the immense conical roof or sikhara with a single metal strip on the top.

\section{Experiencing Sree Padmanabhaswamy Temple}

The much famed Sree Padmanabhaswamy Temple in Thiruvananthapuram ${ }^{2}$ (Fig. 2) is an excellent example of temple architecture in Kerala with the sequence of a series of ascending steps and platforms, Dravidian gopuram and Kerala style nada in the cardinal directions. Chuttuvilakku or array of

1 The temple complex stands on a hillock in the centre of the Thrissur town. According to the inscriptional evidences, the temple is known to have been in existence from A.D. twelfth century, though its foundation could have been much older.

2 Made even more famous after the revelation of hidden gold in its secret vaults giving, the temple the status of one of the wealthiest temples in India. 
lamps encircles the sacred centre, with open courtyards, rising volumes of traditional sloping roofs, an increasing degree of enclosure provided by the perfect wedding of built and unbuilt spaces, small temples oriented around the unidirectional sanctum sanctorum. All these elements combine to accentuate the sacred progression from the corporeal to the spiritual world ${ }^{3}$.

The temple, which stands at the focal point of the fort, consists of the structure of the sanctum sanctorum, the chuttambaam, the belikkal, the flag mast, the chuttuvilakku, the open courtyard and huge gopurams abounding with decorative figures. The seven storied eastern gopuram rises up to a height of $33 \mathrm{~m}$. Built in granite, it bears elaborate temple sculptures and heavy ornamentation. The boat shaped culmination with seven golden kalashas or finials on top gives the gopuram a very dramatic feel. At the garbhagriha one finds the sacred recumbent figure of Lord Sree Padmanabha on the great three coiled serpant chief Anantha, the Lord being viewed through three doors.

Technically the most important feature of the temple structure is the construction technique using a dimensional standardization. The nucleus of the temple plan is the cell containing the shrine with the width of the cell as the basic module of the dimensional system. This proportional system has ensured uniformity in architectural style irrespective of geographical distribution and scale of construction.

To understand the sacredness of this temple: a mere knowledge of its architectural styles, archaeological and curatorial consequences, associated emotional values is just not enough. The realization of the spiritual life and meaning, that has been the backbone of its development, is of much greater significance. This significance is based on the notion of religion as primarily a matter of experience and realization, and not consisting entirely in the observance of rituals and sacrifices ${ }^{4}$.

\section{THE PHILOSOPHY \& SPATIAL CONCEPTS OF KERALA TEMPLE ARCHITECTURE}

The Indian philosophical spatial concepts of the centre, axis and the human relatedness to the cosmic reality are followed conspicuously in the making of the Kerala temples. However, the implementation of the temple built form follow the Vedic religious practices. The spatial organization of a temple is dictated

3 This experience is a product of the devotee's devotional associations provoked by the all existing symbolism linked with the temple.

4 More than the riches, the architecture and sculptural qualities of the temple, the spiritual ambience imparted by the Anananthasayanam posture in eternal sleep of 'yognidra' by the main temple deity, Sree Padmanabhaswamy, a form of Lord Vishnu, has to be revered.
The Physicality And Spirituality Of The Hindu Temples Of Kerala 
Tom, B.

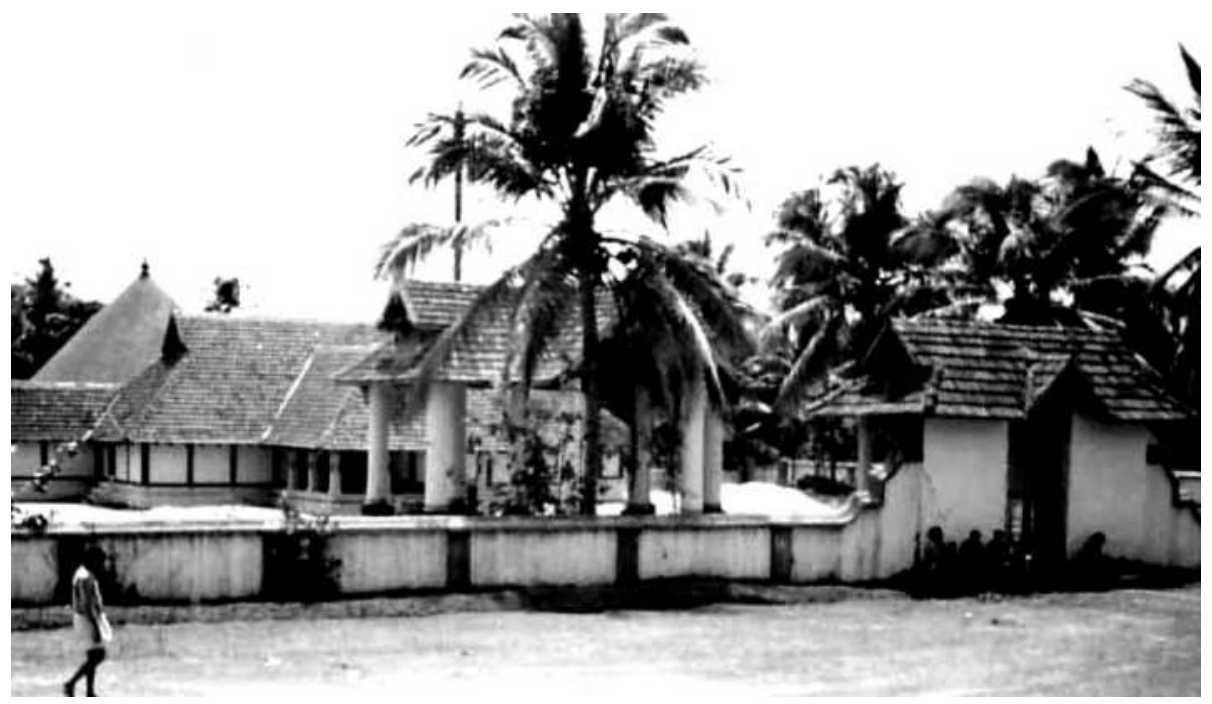

Figure 12: Thrikkakkara Temple displaying the axial arrangement of building units of the temple neighbourhood (Image Source: Binumol Tom)

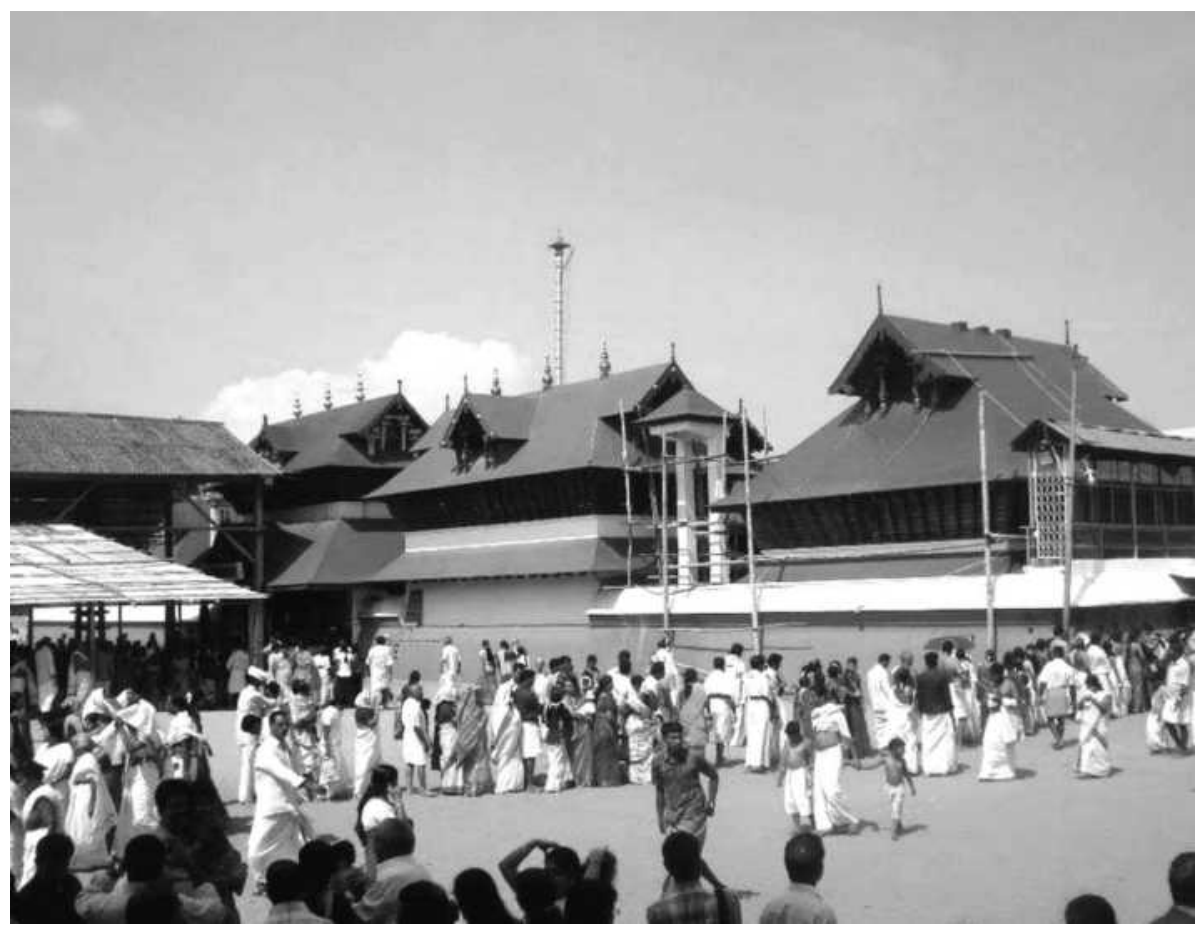

Figure 13: Guruvayoor Sreekrishna Temple (Source: Malenaadu.files.wordpress.com) 


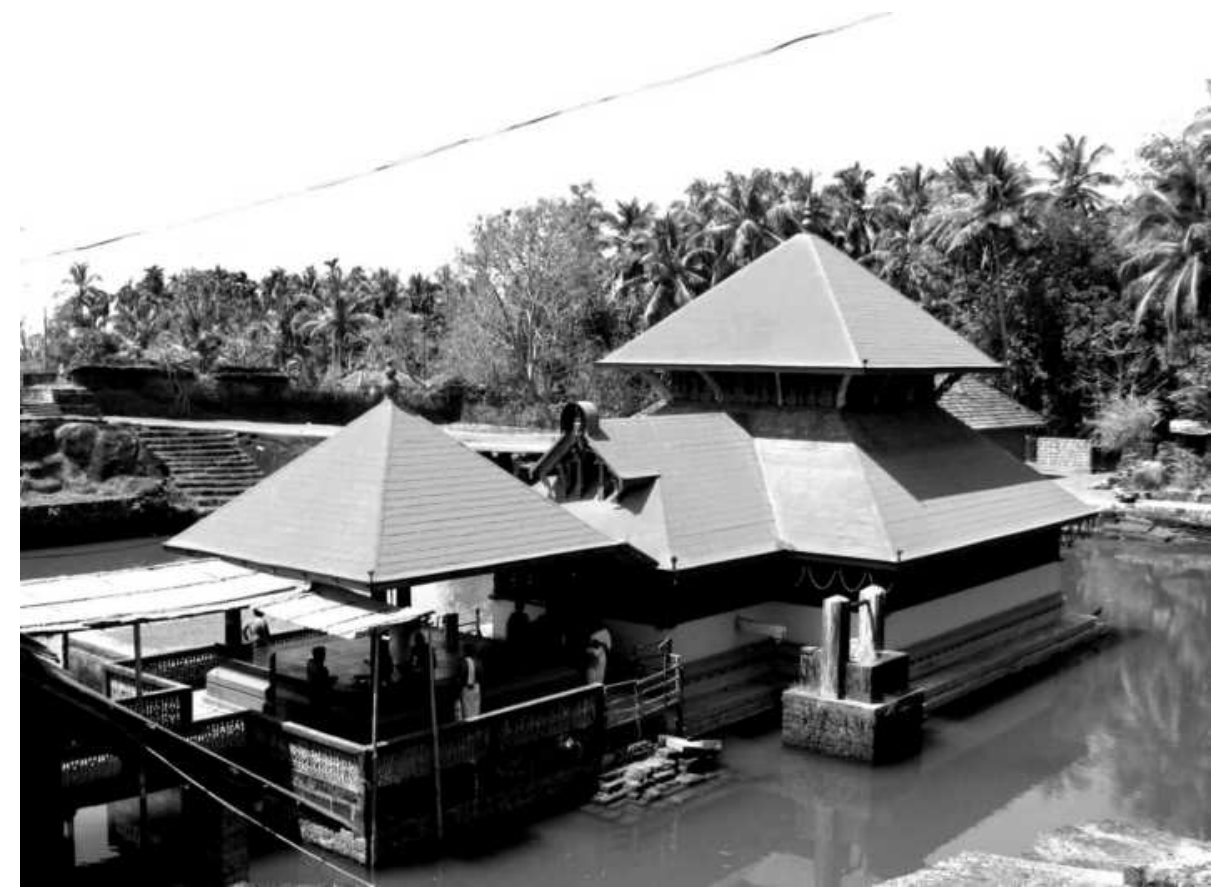

Figure 14: Ananthapadmanabha Temple, Kasarkode. The temple is built on water (Image Source: Binumol Tom)

by the symbolism of the vertical axis joining the nether world (hell) with the sky (heaven) and in the horizontal axis following the cardinal directions. In its existence the concept of spatiality manifests through the axial approach to the main and subsidiary deities and the ritualistic circumambulation to complete the religious visitation (Fig. 12, 13, 14).

\section{Similarity to Domestic Architecture}

Evolution of domestic architecture of Kerala followed the trend of development in temple architecture. The primitive models were huts made of bamboo frame, thatched with leaves in circular, square or rectangular shapes. The rectangular shape with a hipped roof appears to have been finally accepted due to functional considerations. Structurally, the roof frame was supported on pillars or walls erected on a raised plinth. The plinth or lower part is still called adisthana, as in the case of a temple. The sthambas (pillars) and bhithis (walls) are again of simple shapes with no projections or recesses. The main door faces only in one cardinal direction. The rectangular plan is usually
The Physicality And Spirituality Of The Hindu Temples

Of Kerala 
Tom, B.

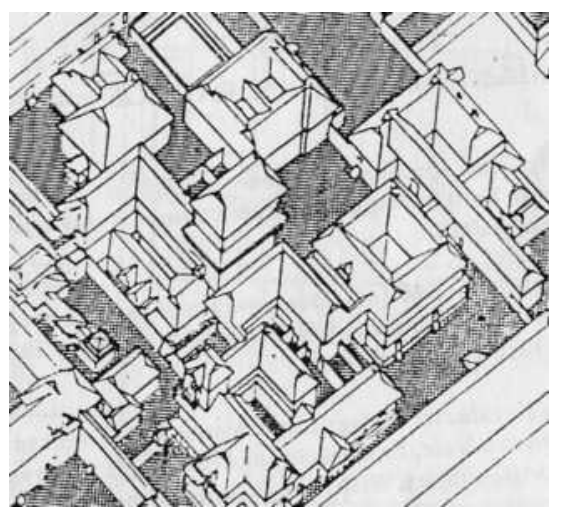

Figure 15: Axonometric view of the courtyards of the Padmanabhapuram Palace (Image Source: Unknown)

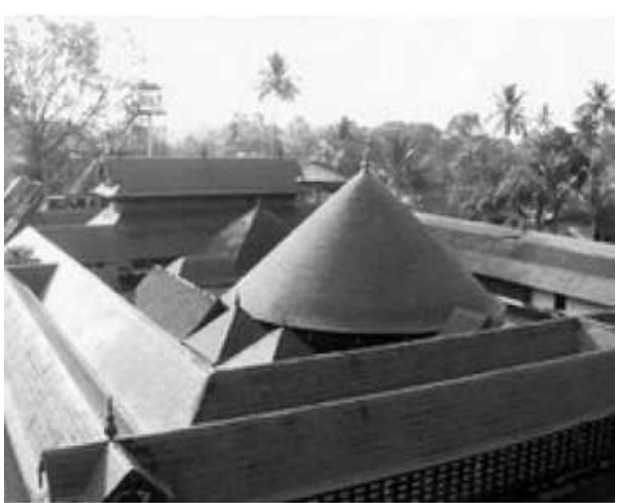

Figure 16: Aerial view, showing the conical roofs of the Thrikaviyoor Mahadeva Temple (Image Source: Unknown)

divided into two or three activity rooms with access from a front passage. The projecting eaves cover a verandah all around. The idea of naallambalam in the temples of Kerala is comparable to that of nalukettu the traditional domestic building consisting of four shalas around a central courtyard. The traditional treatise on domestic architecture "Manushyalaya Chandrika" has been drawn heavily from the Fifteenth Century foundation text on temple construction "Tanthrasamuchaya".

Many similarities may be drawn between secular and religious architecture, which include sophisticated construction and articulation methods as well as techniques, use of materials, craftsmanship and roof system. The terminology prasadam was used to refer to both palace and temple. Conceptually the planning of both the complexes was conceived in the same manner. Just as the garbhagriha of the temple is surrounded by smaller shrines, circumambulatory units, koothambalams etc., so too the palace complex had the main residence of the king surrounded by other service structures (Fig. 15, 16). The temple was conceived as God's abode, where the God was periodically taken out in processions, accompanied by music, dance, rituals, etc.

\section{CONCLUSION}

Religious heritage architecture is a celebration of life as it manifests ideas, encodes messages and evokes feelings in the believers. It communicates through spatial tools and forms a microcosm in cosmos connecting the sensorial, experiential and associational levels of contact between Atman and Brahman, the fundamental basis of any existence. It also nourishes emotionally 
as well as spiritually and so is the case with all the temples found in Kerala. Architecture in all ages has been an expression of social values. In Kerala, a distinct regional character evolved decided by the local materials, climate and aesthetic values. This was propagated from time immemorial through the tradition of guru-shishya parampara (master-disciple legacy).

Kerala's magnificent temples are the focus of the lives of people who follow the Hindu faith. It is the centre of prayer, dance, and all sorts of arts enriching religiously as well as spiritually within everyone associated with the temple. Set in large fields but low in profile, they are excellent examples of architectural marvels based on principles of perfect proportion, simplicity and geometry. The temple complexes extends horizontally, always hugging the earth, the structures emerging in precise response to functional needs, their spacing pulsing to an elegant rhythm of open lanes and covered corridors. Architecturally speaking, the whole growth is organic and the final complex becomes light, spacious and airy.

There is an ordered sequence created by the architectural acumen which is being strictly followed by the devotees, giving them a unique experience in totality, and thus, making the temple a distinct cultural resource, both in terms of physicality and spirituality. Many of Kerala's magnificent temples are hidden in the countryside, along its rivers or high up in the hills. In every instance, the location is chosen carefully and the setting is invariably beautiful. Temples in this land are the focus of the lives of people who follow the Hindu faith. Unlike the grand edifices of the more famous Indian temples, these places of worship are low in profile but offer a tranquility and serenity as a space for prayer that is rare in today's world of frenzied activity.

\section{REFERENCES}

BHATTATHIRIPAD, ANUJAN (Tr.). (1980). Tantrasamuchaya of Chenas Narayanan Namboothiripad. Kunnamkulam: Panchangam Book Stall.

DESAI, MIKI. (2001). Wooden Architecture of Kerala: the physicality and spirituality (Seminar proceedings). Chennai: Madras Craft Foundation.

KATAKAM, RAMU. (2006). Glimpses of Architecture in Kerala. New Delhi: Rupa and Co.

MENON, A. SREEDHARA. (1978) Cultural Heritage of Kerala: An Introduction. Kochi:EastWest Publications.

RAJAN, K. V. SOUNDARA. (1974) Temple Architecture in Kerala; Trivandrum: Government of Kerala

RAPOPORT, AMOS. (2005) Culture, Architecutre, and Design. Chicago: Locke Science Publishing Co., Inc.

RAPOPORT, AMOS. (1969) House Form and Culture. New Jersey: Prentice Hall

SARKAR, H. (1978). An Archaeological Survey of Temples of Kerala, New Delhi: Archaeological Survey of India.
The Physicality And Spirituality Of The Hindu Temples

Of Kerala 